\title{
The British Model in Britain: Failing slowly
}

\author{
Steve Thomas
}

\section{March 2004}

Paper presented at International Workshop on: "Thirty Years of World Energy Policy - cum Editorial Board Meeting of Energy Policy"

Hong Kong Energy Studies Centre \&

Department of Geography, Hong Kong Baptist University

$23^{\text {rd }}-25^{\text {th }}$ March 2004

Public Service International Research Unit School of Computing and Mathematical Sciences University of Greenwich

Park Row Greenwich

London SE10 9LS, UK

Tel: 44 (0) 20-8331 9056

Fax: 44 (0) 20-8331 8665

Email: Stephen.Thomas@gre.ac.uk 


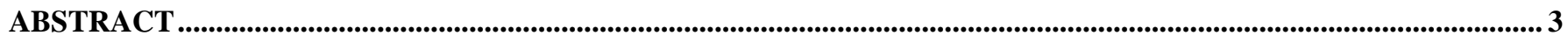

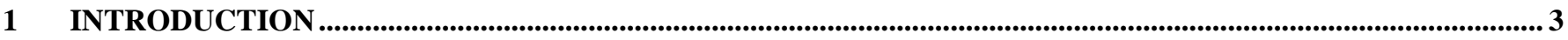

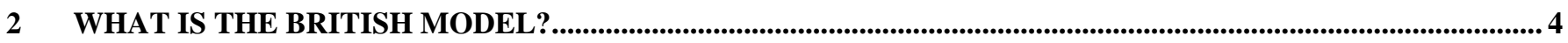

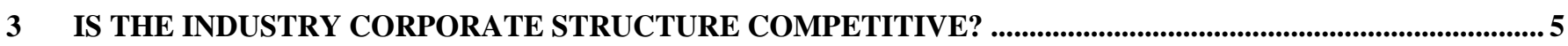

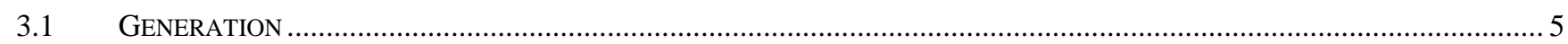

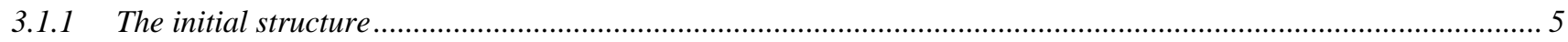

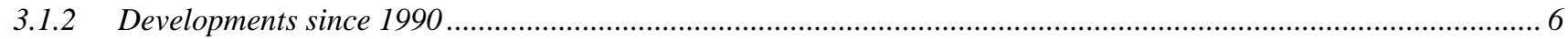

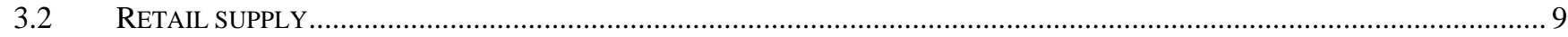

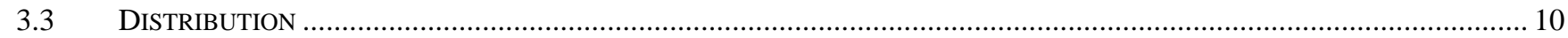

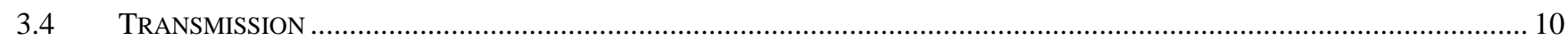

3.5 ASSESSMENT OF THE STRUCTURE

4 IS THE WHOLESALE ELECTRICITY MARKET AN EFFICIENT ONE? ...................................................11

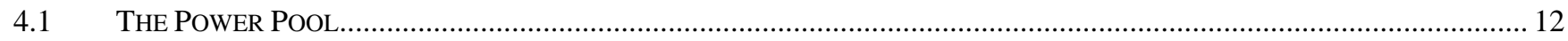

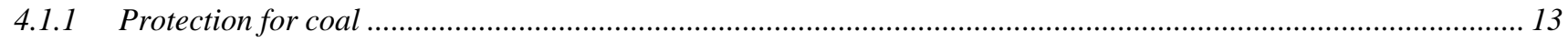

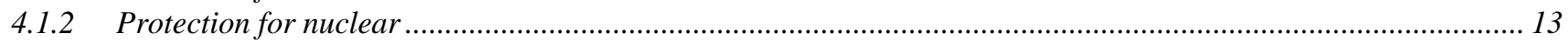

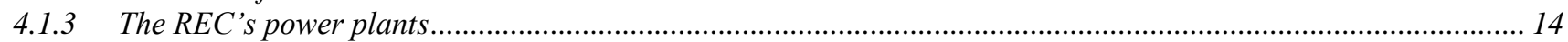

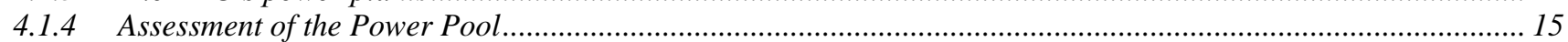

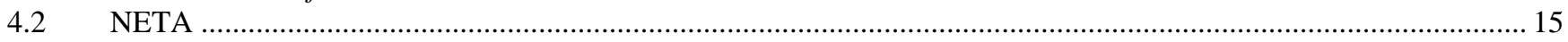

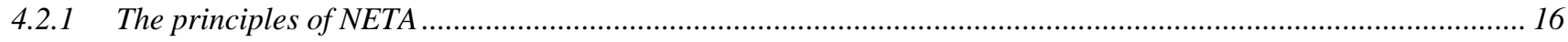

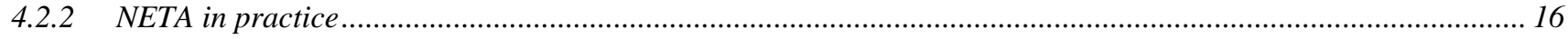

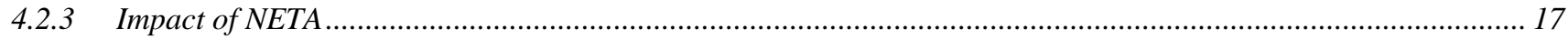

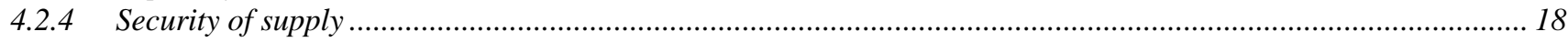

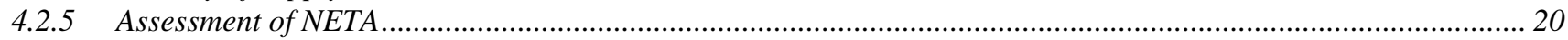

5 IS RETAIL ELECTRICITY COMPETITION RESULTING IN AN EFFICIENT ALLOCATION OF COSTS? 21

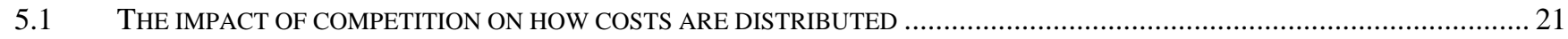

5.2 THE PRACTICALITIES OF INTRODUCING COMPETITION FOR SMALL CONSUMERS ……..........................................2

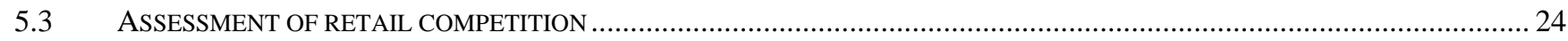

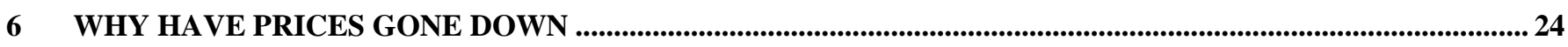

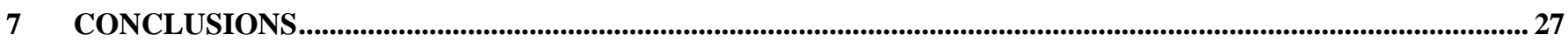




\section{Abstract}

In 1990, Britain became the first developed country to reorganise its electricity industry to run on competitive lines. The British reforms are widely regarded as the benchmark for other reforms and the model used provides the basis for reforms of electricity and other network industries around the world. The factors behind this perception of success are major reductions in the real price of electricity with no apparent reduction in service quality. This paper examines whether the high reputation of the British reforms is justified and whether these good results can be maintained. It concludes that the reputation is not justified and that serious problems are beginning to emerge.

The central question that must be asked is: have the British reforms resulted in the creation of efficient markets at the wholesale and retail level? On this criterion, the reforms have failed. The wholesale market remains illusory. Obscure long-term contracts, privileged access to the market and self-dealing within integrated generator/retailers have dominated wholesale purchases leaving the spot markets with minimal liquidity and unreliable prices. The failure to develop an efficient wholesale market places the onus on consumers to impose competitive forces on electricity companies by switching regularly. Small consumers will not do this and they are paying too much for their power. For the future, there is a serious risk that the electricity industry will become a weakly regulated oligopoly with a veneer of competition.

\section{Introduction}

Britain was the first developed country to reorganise its electricity industry to run on competitive rather than monopoly lines. The reforms, which took place from 1990 onwards, are almost invariably referred to in Britain as privatisation, but elsewhere are termed liberalisation and sometimes de-regulation. None of these terms fully or accurately describes the changes. More than a decade later, the British reforms are widely regarded as the benchmark for other reforms and the model used, often labelled the 'British Model', provides the basis for reforms around the world. The factors behind this perception of success are major reductions in the real price of electricity with no apparent reduction in service quality. For many people there is also a strong presumption that services provided by private companies through competitive markets are inevitably superior to those provided by a publicly-owned monopoly. The European Union seems now to argue that introducing competition in electricity supply is justified not because it is necessarily a better way to deliver the service, but because it is a fundamental right. In the reforms to the European Union Electricity Directive being introduced at the start of 2004, the new draft Directive states:

'The freedoms which the treaty guarantees European citizens - free movement of goods, freedom to provide services and freedom of establishment - are only possible in a fully open market, which enables all consumers freely to choose their suppliers and all suppliers freely to deliver to their customers ${ }^{1}$

This is a political judgement that seems rather hard to justify. If there is not a ground swell of opinion that ability to choose electricity supplier is an important freedom and people are more pragmatic favouring the system that will provide the best combination of price and service, it is all the more important to strip away the rhetoric about competition and private companies to see whether the liberalised model really is superior to the monopoly model of electricity industry.

This paper examines whether the high reputation of the British reforms is justified and whether these good results can be maintained, focusing on the price reductions. It does not examine the question of why reliability has remained high and whether these levels of reliability will continue. The central question that must be addressed is: have the British reforms resulted in the creation of efficient markets at both the wholesale and retail level? It was the promise that the replacement of a monopoly by competitive markets would lead to large efficiency improvements and hence price reductions that was the main rationale for the British reforms. Clearly a competitive process of some sort has been created in Britain as is illustrated

\footnotetext{
${ }^{1}$ Official Journal of the European Union (2003) 'Directive 2003/54/EC of the European Parliament and of the Council, of 26 June 2003, concerning the common rules for the internal market in electricity and repealing Directive 96/92/EC'
} 
by the large number of bankruptcies that have occurred in the British activities of electricity companies since mid-2002. However, the existence of efficient markets implies more than just the possibility of corporate failure: it implies amongst other things, atomistic competition, efficient allocation of resources and low barriers to entry to the industry. The question of whether efficient markets have been created in the British electricity industry can be divided into three parts:

- Is the industry corporate structure competitive;

- Is the wholesale electricity market an efficient one; and

- Is retail electricity competition resulting in an efficient allocation of costs?

Prior to examining these questions, it is necessary to define what the British Model is.

\section{What is the British model?}

The British government has always been evasive about exactly what structure it intended for the reformed electricity industry. The White Paper $^{2}$ and the law ${ }^{3}$ that set out the basis for the reforms did not specify the structure, and subsequent decisions on the industry, such as the $1996^{4}$ and $1998^{5}$ decisions on allowing generators to take over retail companies, and the 2000 Utilities Act $^{6}$ evaded the issue. Nevertheless the logic of the 1990 reforms is clear, and many of the countries that have followed the British Model have embodied the implied structure in law much more fully than Britain. ${ }^{7}$ The four main implied features are:

- Creation of a wholesale spot market as the main price-setting arena for wholesale electricity sales;

- Creation of retail competition so that all consumers can choose their electricity supplier;

- Strict corporate separation of the activities that would remain long-term monopolies, essentially the operation of the network, from activities that would be market-driven; and

- A corporate separation between generation and retail supply.

Two other elements, the adoption of incentive regulation to set the prices for monopoly activities and sale of publicly-owned assets to private investors, were also introduced in Britain but they are not integral to the British Model. The first country to emulate Britain was Norway, in 1991. Its industry remains almost entirely publicly owned (partly national and partly local) and monopoly prices are set by traditional rateof-return methods. Despite this, the Norwegian reforms and the subsequent widening of the Norwegian market to include the other Nordic countries (which also have high levels of public ownership and do not use incentive regulation) are widely regarded as having been successful. ${ }^{8}$ The European Union Electricity Directive puts no requirements on Member States to replace public ownership by private ownership. By contrast, the World Bank, a powerful advocate of the British Model has always presented the privatisation as an essential part of the reform of electricity industries. Indeed, many of the reforms carried out at its instigation have done little more than transfer ownership with only token presence of competition. ${ }^{9}$

\footnotetext{
${ }^{2}$ Secretary of State for Energy (1988) 'Privatising electricity: The government's proposals for the privatisation of the electricity supply industry in England and Wales', Cm 322, HMSO, London

${ }^{3}$ UK Government (1989) 'The Electricity Act', HMSO, London

${ }^{4}$ For an account of the reasoning behind the rejection of the takeover bids, see, Bailey K (1996) 'A bid too far?' Utilities Law Review, vol 7, no 4 pp 134-36

${ }^{5}$ Neither Offer (then the electricity regulatory body) nor the government set down the rationale for the apparent reversal of policy in 1998 on integration of generation and retail supply.

${ }^{6}$ UK Government (2000) 'The Utilities Act, HMSO, London

${ }^{7}$ For example, in Brazil, Colombia and Ukraine, countries that adopted (or in the case of Brazil attempted to adopt) a very close copy of the British reforms, generators are legally prevented from selling electricity to final consumers.

${ }^{8}$ For a comparison of the reforms in the Nordic countries with those in the UK, see A Midttun A \& S Thomas (1998)

'Theoretical ambiguity and the weight of the historical heritage: a comparative study of the British and Norwegian electricity liberalisations' Energy Policy, vol 26, no 2, pp 179-198.

${ }^{9}$ In 2003, the World Bank acknowledged that there was 'declining interest of private sector' and 'decreasing faith in markets'. J Saghir (2003) 'Opening remarks: Energy week 2003’ World Bank, Washington.
} 
One other practical factor to note is that there are actually three separate electricity systems in the UK. Much the largest is that covering England \& Wales and the British Model was only initially applied to this system. The only connection from the UK system to mainland Europe is via a 2000MW DC cable from England to France. The system for Scotland is synchronised to that of England \& Wales but has always been supplied by a separate set of companies. There was strong political opposition in Scotland to the Thatcher privatisation programme and the break-up of the existing companies, and to avoid antagonising the Scottish public more than was necessary, the companies were privatised largely intact as two regional, fully vertically integrated companies with minimal scope for competition. In 1990, the capacity of the connection between the systems was only $850 \mathrm{MW}$, and the scope to trade between the markets was limited. The capacity of the interconnector is now 2200MW making the potential for trade between the two systems much more extensive. As will be shown later, the Scottish system is now being integrated into that of England \& Wales. The third system, geographically isolated, covers Northern Ireland. This was privatised in 1992 with some restructuring but like Scotland with minimal scope for competition. It is now connected by DC link (250MW) to the British mainland system but cannot realistically be fully integrated into the British market. A more likely direction, if political barriers can be overcome, would be to form an Irish electricity market by merging with the Republic of Ireland system.

\section{Is the industry corporate structure competitive?}

A number of factors meant that it was not possible in 1990 to introduce the ideal structure that the British Model, as set out above implies, for the England \& Wales system. This would have required the industry to be de-integrated into two separate competitive activities, generation and retail supply both with a large enough number of competing companies; and two separate monopoly activities, high voltage transmission and low voltage distribution. The factors that prevented this ideal structure being introduced included:

- The unfamiliarity to potential investors of some activities, such as transmission and retail supply as stand-alone activities. This meant the companies would be difficult to value and sell;

- The practical difficulties of setting up a large number of new companies. Setting up a large number of new management structures would be time-consuming and investors would be wary about buying companies with no track record;

- The practical problems of introducing comprehensive retail competition; and

- Political considerations that meant that the British nuclear and coal industries would need at least transitional protection from market forces.

The existing nationalised generator/transmission company, the Central Electricity Generating Board (CEGB) was split into two privatised generating companies, National Power and Powergen, a publicly owned nuclear generator, Nuclear Electric, and a transmission company, National Grid Company (NGC). The 12 existing regional distribution/retail companies (Area Boards) were privatised intact and became known as Regional Electricity Companies (RECs). A Regulator, the Director General of Electricity Supplies (DGES) was appointed assisted by a staff, the Office of Electricity Regulation (Offer). Subsequently, the single person Regulator was replaced by a board, the Energy Markets Authority and the regulation of electricity and gas was merged and Offer became the Office of Gas and Electricity Markets (Ofgem). ${ }^{10}$

\subsection{Generation}

\subsubsection{The initial structure}

The government's commitment to nuclear power was one of the factors that prevented the creation of a competitive field of generation companies. The government initially believed that Britain's nuclear plants,

\footnotetext{
${ }^{10}$ For an account of the regulatory arrangements, see S D Thomas (2001) 'Theory and practice of governance of the British electricity industry’ International Journal of Regulation and Governance, vol 1, no 1, pp 1-24.
} 
then providing about 15 per cent of electricity supplies, could be privatised only if they were 'sheltered' in a large company, which would own two thirds of the generating capacity. To provide some countervailing power to this dominant company, the rest of the plants would be placed in only one other company. In the event, even the shelter of a large company was not sufficient to make the nuclear plants attractive to investors, but this became clear to the government less than six months before privatisation, too late to reconsider the structure. ${ }^{11}$ The fossil fuel plants were allocated as planned, so one privatised company, National Power, had about half the total capacity (30GW), Powergen had a third of the capacity (20GW) and a publicly owned company, Nuclear Electric was given the nuclear plants $(8 \mathrm{GW}) .{ }^{12}$ The nuclear company was heavily subsidised by consumers (half its income came from a subsidy) and was a pricetaker so the generation market was effectively a duopoly.

\subsubsection{Developments since 1990}

The initial structure allowed the 12 RECs to acquire up to 15 per cent of their power from plant in which they had significant ownership shares. Most of the RECs quickly moved towards this limit and in the socalled 'Dash for Gas' from 1990-92, the RECs bought about half of the 20GW of plant ordered in that time. This allowed the RECs to diversify their business and also reduced their dependence on the duopoly. The household market (50 per cent of the market) was expected to be captive until at least 1998 and the RECs were able to pass on any risk from this investment to the captive market. It was not clear why this violation of the principle of separating generation and retail was incorporated in the regulations. The principle of separation of generation and retail was compromised even more by the decision to allow National Power and Powergen to supply power to final consumers in the competitive part of the retail market. The most likely explanation for these compromises is that they were pragmatic steps to reduce the market power of the duopoly and to kick-start retail competition. A fully independent new entrant generator would have stood little chance against the market power of the duopoly and allowing the RECs to build new plant seemed the only plausible way to reduce the market share of the duopoly. In the retail market, the RECs initially bought their power on the same terms as each other and it was hard to see how one supplier could offer cheaper terms than another.

The generation structure was clearly not competitive and by 1993, the Regulator had become impatient with what he saw as manipulation of the wholesale (Pool) price by the duopoly. ${ }^{13}$ The Regulator imposed a 'cap' on the Pool price (see later) and required that by 1996, National Power and Powergen sell off $4 \mathrm{GW}$ and $2 \mathrm{GW}$ respectively of their existing generating capacity to new entrants. This was carried out in 1996, but only at the expense of further compromise to the principle of separation of generation and retail. The plant was all sold to the largest REC, Eastern Electricity, which was allowed to break the 15 per cent limit. Separation of generation and retail was further eroded by the government allowing Scottish Power, the larger of the two Scottish integrated companies, to take over a REC, Manweb, in 1995. Increases in the capacity of the Scotland-England interconnector, generation overcapacity in Scotland and the payment of the nuclear subsidy to electricity generated in Scotland that was supplied to England meant that Scottish Power could easily compete effectively as an integrated company in England \& Wales supplying power from its Scottish power stations to consumers in England \& Wales.

However, when National Power and Powergen tried to take over RECs in 1996, they were blocked by the government supported by the Regulator. ${ }^{14}$ The minister over-rode the recommendation of the Monopolies

\footnotetext{
${ }^{11}$ In evidence to the Energy Select Committee, the Secretary of State for Energy at the time of privatisation, John Wakeham said 'If I was starting from scratch I would not have decided to split the CEGB fossil stations into two companies'. House of Commons Select Committee on Energy, 'The cost of nuclear power ', fourth report, session 1989-90, HC205-I, para 6

${ }^{12}$ The Scottish nuclear plants were also withdrawn from the privatisation and put in a new company called Scottish Nuclear

${ }^{13}$ Office of Electricity Regulation (1995) 'Text of letter from DGES to National Power and PowerGen concerning the undertakings on sale or disposal of plant' Office of Electricity Regulation, Birmingham

${ }^{14}$ See K Bailey (1996) op cit, Department of Trade and Industry Press Release (1996) 'Ian Lang blocks electricity mergers' Department of Trade and Industry, P/96/313, 24 April 1996 and Monopolies and Mergers Commission (1996) 'National
} 
\& Mergers Commission inquiry he had ordered, which found that the takeovers would be acceptable provided some conditions (not expected to be onerous) were met. ${ }^{15}$ The government justified this apparently contradictory decision by saying that integration of retail and generation was not wrong as such, but that the market power of the duopoly was too strong to allow them to integrate.

In 1998, when the duopoly tried again, the New Labour government caved in and allowed them to take over retail businesses without reference to the Monopolies \& Mergers Commission, on the condition that they both sold a further $4 \mathrm{GW}$ of their plant. How far this was a pragmatic decision based on a recognition that the principle of de-integration had already been surrendered and how far it represented a conscious decision to allow the market to integrate is not clear. An alternative explanation is that the moves to separate distribution and retail then being required would have left the retail sector as too vulnerable. A retail business has few assets other than customer loyalty and if the retail businesses were forced to operate as stand-alone companies, they might have proved not to be sustainable businesses. If they could not be integrated with distribution, integrating with generation might have been the only viable option. Again the government was not explicit in its motives. By then, it was clear that National Power and Powergen were unlikely to become strong international players. The Regulator was not content to allow them a dominant position in the British market that could underwrite international ventures, they had both already made serious errors in gas procurement that required them to write off nearly a billion pounds in uneconomic contracts and their early ventures into international markets had proved problematic.

\section{Table 1}

\section{0}

1. London

2. SWEB

3. Seeboard

4. Eastern

5. Norweb

6. East Midlands

7. South Scotland

8. Manweb

9. North Scotland

10. SWALEC

11. Southern Electric

12. Yorkshire

13. Midlands

14. Northern

\section{Ownership of retail supply businesses: 1990 and 2004}

\section{4}

1. EDF (London (1998), SWEB (1998), Seeboard (2002))

2. Powergen/E.ON (Eastern (2002), Norweb (2002), East Midlands (1998))

3. Scottish Power (South Scotland, Manweb (1995))

4. Scottish \& Southern (North Scotland, Southern (1998), SWALEC (2000))

5. Innogy/RWE (Yorkshire (2001), Midlands (1998), Northern (2001))

Source: Author's research.

Note: The dates of takeover are shown in brackets.

This decision opened the floodgates to integration. Within a couple of years, all 12 of the RECs' retail businesses in England \& Wales had been taken over by companies with large British generation interests including the two Scottish companies (Table 1). The two regions of Scotland must now be counted as part of a British market and the 14 retail regions of Britain are now in the hands of just five companies. National Power got into serious financial difficulties and in 2000, to survive, had to split itself into a UK only business, Innogy, and an international independent power producer business, International Power. Innogy and Powergen, weakened by poor fuel purchases and ill-advised foreign investments, were taken over by German companies, RWE and E.ON respectively, in 2001. The government took open-ended

Power plc and Southern Electric plc: a report on the proposed merger', Cm 3230, The Stationery Office, London, and, Monopolies and Mergers Commission (1996) 'PowerGen plc and Midlands Electric plc: a report on the proposed merger', Cm 3231, The Stationery Office, London

${ }^{15}$ Monopolies and Mergers Commission (1996) 'National Power plc and Southern Electric plc: a report on the proposed merger', Cm 3230, The Stationery Office, London, and, Monopolies and Mergers Commission (1996) 'PowerGen plc and Midlands Electric plc: a report on the proposed merger', Cm 3231, The Stationery Office, London. 
'golden shares' in National Power and Powergen in 1990 but by 2000, the legality of the golden shares under European Union competition law was in doubt and the government chose not to exercise its golden shares to prevent these changes. EDF entered the market by taking over RECs and buying some of the capacity released by the duopoly. TXU, a US utility that built an integrated business around its ownership of the Eastern REC and the purchase of generating plant from National Power and Powergen, made some poor power purchase deals, went bankrupt in 2002, and was taken over by Powergen/E.ON.

A sixth company, Centrica (the demerged retail business of the former national gas company, British Gas that still trades in Britain as British Gas) has about 24 per cent of the household electricity market and about 63 per cent of the household gas market but a negligible share of the market for larger gas and electricity consumers. ${ }^{16}$ It has also invested in generating plant, but its key asset is clearly its brand name. Its position is described in more detail in Section 5.

The other significant development was the privatisation of the more modern nuclear power plants. After the failure to privatise these in 1990, the government committed itself to carry out a review of its nuclear power policy in 1994. Nuclear Electric (and Scottish Nuclear) was remarkably successful in improving the reliability of the more modern nuclear plants, doubling their output. The government review was published in $1995^{17}$ and recommended that the more modern nuclear plants in England and Scotland ${ }^{18}$ with a capacity of about $9 \mathrm{GW}$ be privatised and that the nuclear subsidy removed. In 1996, British Energy was floated on the Stock Exchange raising only £2.1bn despite the fact that it included eight plants, the most recent of which had been completed a year earlier at a cost, paid by electricity consumers, of over $£ 3$ bn pounds. The older plants were left in public ownership in a new company, Magnox Electric, which was later absorbed into the nationally owned nuclear fuel cycle and waste disposal company BNFL.

British Energy prospered initially, its share price peaking at over $£ 7$ a couple of years later compared to a flotation price of about $£ 2.40$. However, by 2000 , falls in the wholesale electricity price were eating into profits and by autumn 2002, it had to receive a government loan of $£ 650 \mathrm{~m}$ to stay in business. In February 2004, it was not clear whether this would be judged an unfair state aid by the European Commission and the company may not survive. Attempts to save the company will mean that a large part of the long-term liabilities of the company (decommissioning and waste disposal) will fall on future taxpayers. A National Audit Office report of February 2004 was highly critical of the government for failing to monitor the extent of the risk of privatising British Energy on public funds. ${ }^{19}$ The Magnox plants are only a small part of BNFL's overall operations. BNFL is also bankrupt and is being kept in business by government support. The Magnox plants lost $£ 159 \mathrm{~m}$ in fiscal year 2002/03.

If we look at generation, the market appears competitive (Table 2). Eight companies have more than 3 per cent of the market and no company has more 15 per cent of the market. However, closer examination shows a much less healthy picture. 40 per cent of the capacity is owned by companies that are bankrupt or has been repossessed by banks from bankrupt companies or is held by companies that have been trying to sell the plants for at least a year at distress prices. Much of the $9.2 \mathrm{GW}$ of plant that is owned by 'others' is part-owned by the integrated companies or is contracted long-term to them. It cannot be described as

\footnotetext{
${ }^{16}$ Ofgem (2003) 'Domestic gas and electricity supply competition: Recent developments' Ofgem, London

${ }^{17}$ Department of Trade and Industry and the Scottish Office (1995) 'The prospects for nuclear power in the UK: Conclusions of the government's nuclear review' Cm 2860, HMSO, London.

${ }^{18}$ Three designs of commercial nuclear power plant have been built have been built in Britain. Nine stations, completed from 1963-72 are of the Magnox design and in 2004, 4 of these remained in service (about 3GW). Seven stations, completed from 1976-1989 are of the AGR design (about 8GW) and one PWR, completed 1995 was built.

${ }^{19}$ National Audit Office (2004) 'Risk Management: The Nuclear Liabilities of British Energy plc', National Audit Office HC 264 Session 2003-2004: 6 February 2004
} 
independent. By contrast, EDF, E.ON and RWE are doing very well in the British market making a significant proportion of their profits there. ${ }^{20}$

Table 2 Ownership of generating capacity: 1990 and 2004

$\begin{array}{llll}\text { 1990 (Capacity GW) } & \mathbf{2 0 0 4} \text { (Capacity GW) } & \\ \text { National Power } & 30 & \text { British Energy (nuclear: bankrupt) } & 9.6 \\ \text { Powergen } & 20 & \text { *Innogy (RWE) } & 8.0 \\ \text { Nuclear Electric } & 8 & \text { *Powergen (E.ON) } & 8.3 \\ & & \text { *Scottish \& Southern } & 5.3 \\ & \text { *Scottish Power } & 4.7 \\ & \text { *EDF } & 4.7 \\ & \text { BNFL (nuclear: bankrupt) } & 2.7 \\ & \text { *Centrica } & 2.2 \\ & \text { Others } & 9.2 \\ & \text { Plant repossessed by banks etc } & 7.9 \\ & \text { Plant for sale } & 6.3 \\ & \text { TOTAL } & 68.9\end{array}$

Source: Author's research.

Notes: Companies with generation and retail supply are marked *.

\subsection{Retail supply}

The 12 RECs combined the distribution and retail functions under single ownership, although an accounting separation between the businesses was required. In terms of income, distribution was much the larger business than retail contributing about 90 per cent of income. The companies were protected from takeover by golden shares for only 5 years. Once the golden share expired, they were all soon the subject of takeover bids and only one, Southern Electric, was not taken over in the following two years. The new owners, mostly US utilities, seem to have had little strategic vision for the companies. In 1997, the Regulator became concerned about the scope for cross subsidy between the distribution and retail businesses. While there was an accounting split, about a quarter of systems and a significant proportion of staff were common to both businesses. The Regulator feared that companies would cross-subsidise their competitive retail businesses from their monopoly distribution businesses choking off competition. He therefore required a full physical separation of the businesses so there was no scope for cross-subsidies. The businesses could remain under common ownership but in all other respects had to be fully separate. There does not seem to have been any clear evidence that any cross-subsidies were materially affecting competition. By 1997, most medium and large consumers were changing their supplier or renegotiating terms each year and the RECs no longer had dominant shares for such consumers in their home territories. It seems more likely that the Regulator was concerned that such cross-subsides could stifle competition in the household sector, which was then expected to be opened in $1998 .^{21}$

The two businesses, distribution and retail, have little in common in terms of skills - distribution is mainly concerned with maintaining a physical network while retail is concerned with buying and marketing a commodity. So given there could now be no commercial advantage in keeping the two businesses in common ownership, many of the previous owners chose to split up the businesses. As shown above (Table 1), the retail businesses were quickly bought by generators.

\footnotetext{
${ }^{20}$ In 2002, EDF's UK operations made up 9 per cent of EDF Group sales, but 37 per cent of net profits (see EDF Annual Report and Accounts, 2002). In the first 3 quarters of 2003, RWE reported that Innogy was a 'major contributor to improved operating results (see http://www.rwe.com/app/presse/Anzeige.aspx?id=3576797). Associated Press Worldstream reported that for E.ON: 'Nine-month revenues rose 33 percent, to $€ 33.29$ billion ( $€ 38.28$ billion) from $€ 25.05$ billion, the company said, with much of the increase coming from Powergen and latest acquisition Ruhrgas of Germany.'

${ }^{21}$ Offer (1998) 'Reviews of Public Electricity Suppliers 1998 to 2000, Separation of businesses: Second consultation paper' Offer, Birmingham
} 


\subsection{Distribution}

The distribution businesses of the 12 RECs began split from the retail businesses after 1998. By 2004, the distribution businesses of half of the 14 regions of England, Wales and Scotland were owned by companies other than the owner of the retail business. This raises a number of issues, but from the point of view of assessing how efficient markets are, the strong regulatory requirement for de-integration of retail and distribution means there is no issue of access to distribution networks. It is clear that all retailers now have equal access to distribution networks on non-discriminatory terms. Perceptions of how to separate the network from the commercial activities have changed since 1990 and now, in liberalisation measures worldwide, there is more emphasis on control of the assets than an ownership. The Distribution System Operator (DSO), in other words, the organisation that determines how the network is used, is the key factor not the asset owner. In Britain, the DSO has invariably been the asset owner. For the future, if as seems likely, the proportion of power generated by small sources that feed directly into the distribution network rather than the transmission network increases, the role of DSO will be much more challenging.

As with retail, ownership of the 14 original regions is concentrating. However, the set of owners is somewhat different (Table 3). Most companies, including EDF, Scottish Power, Powergen and Scottish \& Southern have chosen to operate in both distribution and retail. Innogy has not bought into distribution, while the US companies PPL and Mid-American Energy Holding, and United Utilities (mainly a UK water company) have sold their retail businesses. The number of independent companies is probably still sufficient for the regulator to be able to use 'yardstick' methods for setting distribution prices, but a further reduction in the number of independent companies would make such methods difficult.

Table 3 Ownership of distribution businesses: 1990 and 2004

\section{0}

1. London

2. Eastern*

3. Seeboard

4. SWEB*

5. SWALEC*

6. South Scotland

7. Manweb

8. North Scotland

9. Southern Electric

10. Northern*

11. Yorkshire*

12. Norweb*

13. East Midlands

14. Midlands*

Source: Author's research.

Notes

1. Distribution companies that have split from the retail business are marked $*$

2. Companies marked $\uparrow$ own adjoining distribution regions.

3. PPL acquired a 25 per cent stake in SWEB in 1996, it raised its holding to 51 per cent in 1998 and acquired the remaining stock in 2002.

\subsection{Transmission}

A priority for the government in the 1990 structure was to ensure that transmission was not in the hands of a generator, as this would have led to fears that access to the network would not be fair. However, government was concerned that investors would not be able to value a transmission company and that the business would not be strong enough to allow investment needs to be financed. The company, National Grid Co (NGC) was therefore jointly owned by the 12 RECs, but with limitations on how far they could influence its policies. By 1995, a number of factors meant this arrangement was ripe for review. The 
concerns about financial strength proved unfounded, the financial record of NGC was good, giving confidence to investors, and ownership by the RECs was restricting the scope of NGC. The RECs were therefore required to sell their shares. There does not seem to have been major concern that the RECs would use their ownership of NGC to give advantage to their retail businesses. In 2003, NGC merged with its equivalent in the gas industry, Transco, to form National Grid Transco. The company now has major electricity network assets in New England. It is still protected by a government golden share, but as yet, this strength of this protection has not been tested. As with the distribution companies, NGC is owner of the assets as well as the Transmission System Operator (TSO). From the perspective of competition, NGC is clearly independent and all competing generators clearly have equal access to the grid.

\subsection{Assessment of the structure}

The decision to allow integration of generation and retail and to allow the structure to concentrate to the extent it has means the structure in both generation and retail is not competitive and there seem few realistic policy options for making the structure more competitive. In generation, the government may try to keep most of the nuclear plants in service for its own reasons ${ }^{22}$. However, nuclear will provide baseload power as a price-taker and will not contribute to competition in the wholesale market. Some of the bankrupt or near-bankrupt fossil fuel plants may be bought by the integrated companies or may survive through long-term contracts to them, while some will be retired. But there will be little independent power to provide liquidity to the wholesale market.

Of the six integrated companies, the parent companies of the three foreign owned companies are much larger than the three British-owned companies. The position of Centrica is relatively weak, surviving primarily on its brand name ${ }^{23}$, while the two Scottish companies may not have the scale to continue as independent companies. In a few years, unless there is determined action by the government to prevent further concentration, the British market could be dominated by just three or four companies. These companies will have no interest in competing hard against each other and there will be little prospect of new entrants to compete against. Who will buy the power of potential new generators and who will sell power to potential new retailers?

The one apparent success with the structure has been the commercial separation of network activities from the competitive activities so there have been no concerns about access to the networks. However, given the uncompetitive structure of generation and retail, this is a hollow victory.

\section{Is the wholesale electricity market an efficient one?}

The creation of a highly competitive wholesale electricity market was the centrepiece of the British reforms. In 1990, the cost of generation comprised about 60 per cent of the retail price of electricity $(65$ per cent if we include the nuclear subsidy). Most of the rest of the price of electricity was accounted for by monopoly charges, distribution (about 25 per cent) and transmission ( 5 per cent). There seemed little reason beyond the rather speculative impacts of changing ownership and introducing incentive regulation why privatisation would reduce these regulated costs. There was no empirical evidence to support the hypothesis that privately owned electric utilities are more efficient than publicly owned utilities, indeed, what little evidence did exist suggested the opposite. ${ }^{24}$

\footnotetext{
${ }^{22}$ Without the nuclear stations, Britain would find it difficult to meet its targets on greenhouse gas emission reductions. Closing the nuclear plants would also lead to heavy public expenditure on decommissioning and would expose the lack of capacity for the final disposal of waste.

${ }^{23}$ In 2002, Centrica's residential sales business contributed only 26 per cent of group profits despite accounting for 42 per cent of sales. Most of the profits (56 per cent) came from its gas production business.

${ }^{24}$ Pollitt, M.G. (1995), Ownership and Performance in Electric Utilities. (240pp), Oxford: Oxford University Press / Oxford Institute for Energy Studies.
} 
It was the vision of generation companies competing with each other every half hour of every day to supply the system that promised significant price reductions. Indeed, some commentators advocated that the CEGB's power stations be sold individually to create real atomistic competition. ${ }^{25}$ Political and practical considerations meant the vision of intense competition could not immediately be realised.

\subsection{The Power Pool}

The wholesale market that was introduced in 1990 and continued until 2001 was known as the Power Pool. The principles of the Power Pool were clear:

- Supply and demand would be balanced every half hour;

- All generators would have to make a successful bid into the Pool to operate their plants;

- The Pool price would be set by the highest successful bid and paid to all successful bidders;

- Retailers would have to buy all their supplies from the Pool at Pool price.

The attraction of a compulsory market was that it appeared to make barriers to entry for new generators and on retailers very low. The only requirement on a new generator was that they could produce power at economic costs. They did not have to find a customer for their power. The White Paper foresaw that 'the grid company will be calling up the generators which offer the cheapest energy [to the Pool]'. ${ }^{26} \mathrm{New}$ retailers could acquire supplies easily on essentially the same terms as their competitors.

However, this advantage was lost, at least initially, by the extent and nature of bilateral contracting that was allowed. Such contracts were invariably drawn in a form that meant that generators and suppliers were paid the contract price regardless of the actual Pool price: any difference between the Pool price and the contract price was settled bilaterally between the generator and the supplier - a contract for differences (CfD). These contracts, which insured the price received by generators, led generators covered by CfDs to bid a price of zero into the Pool simply to ensure the plants were dispatched.

Time pressures on the development of the software meant that ambitious Pool designs had to be dropped and the CEGB's old dispatching software had to be hurriedly adapted. This led to practical difficulties throughout the life of the Power Pool from 1990-2001 because of the age and inappropriateness of the software. However, perhaps the major practical problem was the capacity payment mechanism, which was, from the start, abused by the generators. ${ }^{27}$ This led to an unpredictably fluctuating Pool price, which meant that generators and retailers had no confidence in the Pool and inevitably relied on contracts not linked to the Pool price for their purchases and sales.

The Regulator acted in 1993 to prevent abuse of the Pool price by the duopoly requiring that the average Pool price be at or below a specified level from 1994-96 and also requiring the divestments discussed previously. ${ }^{28}$ This requirement was met very accurately demonstrating the control over the Pool price that the duopoly exerted. However, the requirement was only to maintain the annual average at or below the specified level and in fact, after this 'cap' was introduced, the variability of the Pool price increased significantly so confidence in the Pool was not built. ${ }^{29}$

\footnotetext{
${ }^{25}$ A Sykes \& C Robinson (1987) 'Current choices: Good ways and bad to privatise electricity’ Centre for Policy Studies, London

${ }^{26}$ Secretary of State for Energy (1988) 'Privatising electricity: The government's proposals for the privatisation of the electricity supply industry in England and Wales', Cm 322, HMSO, London

${ }^{27}$ For an account of the capacity payment mechanism, see S D Thomas (1997) 'The British Market Reform: a Centralistic Capitalist Approach' in 'European Electricity Systems in Transition' ed Atle Midttun, Elsevier, 1997.

${ }^{28}$ Office of Electricity Regulation (1995) 'Pool prices and the undertakings on pricing given by National Power and PowerGen' Office of Electricity Regulation, Birmingham

${ }^{29}$ L Phillips (1995) 'European Electricity Liberalisation: Lessons from the UK' MC Securities, London
} 


\subsubsection{Protection for coal}

The government had no wish to protect the British coal industry, indeed, ministers of the time have subsequently admitted that an objective of electricity privatisation was to break the power of the main mining union ${ }^{30}$, but British-mined coal was produced at above world market price and if generators were given freedom to buy coal where they wanted, the British coal industry would have collapsed overnight with severe social consequences. As a result, the government required the two generators to contract for large quantities of coal from the nationalised coal company, British Coal, for three years. The volumes corresponded to about the same amount as was used before privatisation, equivalent to about 60-70 per cent of generation and prices were to fall to world market levels by the end of the contract. The generators argued this would put them at a disadvantage compared to new entrants and as a result, the government required the RECs to buy all the power generated by British coal under CfDs and the RECs in turn were assured they could allocate this power to the captive market (from 1990-94, this was 70 per cent of demand). The agreement to allocate this expensive power to the captive market is hard to square with the requirement on the regulator and the minister to ensure that 'a public electricity supplier shall not show undue preference to any person or class of persons, and shall not exercise any undue discrimination against any person or class of persons on the companies. 31

The contracts were renewed for a further five years in 1993, again with declining real prices and volumes, so that by 1998, about 40 per cent of generation was covered by this contract and prices were 30 per cent lower in real terms compared to 1990. British Coal was privatised in 1995, with most of the capacity going to RJB Mining. The RECs were obliged to buy the output of this plant and were allowed to allocate this power to the captive market. The effects of 1990-93 and 1994-98 contracts were:

- The 70 per cent falling to 40 per cent of generation provided by this coal was taken out of the wholesale market for the period 1990-98;

- The generators were guaranteed good profits from these contracts as analysis shows that the price they received for the power meant they could keep the coal price reductions as extra profit ${ }^{32}$;

- Small consumers, who were allocated this expensive power, were paying, by 1997, about 30 per cent more for their generation than non-captive consumers (see next section for further details); and

- The British mining industry, which had no other credible markets for its coal, was effectively destroyed. The implausibility of long-term contracts for British coal beyond 1998 meant that investment in new mining capacity could not be justified and needs from 1990-98 were largely met by depleting already developed seams.

\subsubsection{Protection for nuclear}

The government promised to promote nuclear power in its 1987 election manifesto. ${ }^{33}$ As noted above, the original plan to privatise the plants as part of National Power proved impossible. The operating cost alone of the nuclear plants was found to be about double the expected market price. So, as with coal, if the government had not introduced some protection against market forces for nuclear, the sector would have collapsed overnight. The government introduced a consumer subsidy that initially accounted for about half Nuclear Electric's income and was designed to be just sufficient to keep Nuclear Electric solvent. The subsidy guaranteed Nuclear Electric's income, and its form meant that its income did not depend on the Pool price. The RECs were obliged to buy all the power produced by the nuclear power plants, paying the Pool price. The government intended the subsidy to be open-ended but the European Commission

\footnotetext{
${ }^{30}$ See for example, N Ridley (1991) 'My style of government', Hutchison, P Walker (1991) 'Staying Power', Bloomsbury, C Parkinson (1992) 'Right at the centre', Weidenfeld \& Nicholson, and N Lawson (1992) The view from no 11' Bantam press.

${ }^{31}$ UK Government (1989) 'The Electricity Act', HMSO, London

${ }^{32} \mathrm{~S}$ Thomas (2000) 'Has privatisation reduced the price of power in Britain?' Unison, London.

${ }^{33}$ Conservative Party Manifesto (1987) 'The next moves forward', Conservative Party, London.
} 
judged it an unfair state aid and required it be removed by 1998. As a matter of presentation, the British government described the subsidy as a 'Fossil Fuel Levy'. This meant that it had to go to all forms of generation that did not use fossil fuels. So a small proportion was paid to a renewables programme and, more importantly, since French and Scottish generators argued that exports to England \& Wales were provided by nuclear or hydro plants, the subsidy also had to be paid to all imports, making exports from France and Scotland highly profitable to the exporters. While the subsidy was in place, the cable from France to England was about 99 per cent fully loaded with imports from France.

The expectation in 1990 was that the seven remaining Magnox plants (the first generation British nuclear power plants) would be retired by about 2000 because of their age and because no improvement in their economic performance could be expected. The newer plants, the Advanced Gas-cooled Reactors (AGRs), suffered from appalling unreliability (an average availability of about 40 per cent in 1989) and at least some of these were expected to be closed. It was clear that the one unit (Sizewell B, a Pressurised Water Reactor or PWR) under construction would not be able to recover its costs and there was pressure to abandon it. Events turned out very differently. ${ }^{34}$ By 1995, only one of the Magnox plants had been retired, the Sizewell B unit had been completed and seemed likely to operate reasonably reliably and output of the AGRs had nearly doubled. This meant that the AGRs and Sizewell B appeared able to more than cover their operating costs from receipts from the Pool and allowed these plants to be privatised in 1996. The share of nuclear rose from about 15 per cent to more than 25 per cent. The effect of this protection for nuclear on the wholesale market in England \& Wales was:

- The 15 per cent, rising to 25 per cent of demand provided by nuclear power was taken out of the market;

- A further 10 per cent of demand was supplied by heavily subsidised imports; and

- Because retailers did not have to pay the subsidy on the nuclear plant and imported supplies and the Pool price was well below the coal contract prices, nuclear and imported power was relatively cheap to them and they allocated these sources to the competitive market.

\subsubsection{The REC's power plants}

The RECs were uncomfortable receiving most of their power from the duopoly. When negotiations began between the RECs and the duopoly in 1991 about renewal of the 1990-93 contracts, the price offered by National Power and Powergen was above the 1990-93 levels. New gas-fired plant was expected to generate at well below this price so the case for the RECs to build as much new generating capacity as possible seemed overwhelming. The new plant would reduce their dependence on the duopoly, would be cheaper than existing supplies, would expand their business and any additional cost could be passed on to captive consumers at least until 1998 when the market was expected to open. As a result, the RECs ordered about 10GW of plant from 1990-92, contracted to themselves (under contracts for differences) for 15 years and with matching 15 year largely fixed-price take-or-pay base-load gas supply contracts at gas prices that seemed advantageous. This plant began to come on stream in 1994 and by 1998 was able to contribute about 20-25 per cent of British demand. The gas price proved far from economic and by 1994, the market price had halved leaving this plant far more expensive than new gas-fired plant that was up to 20 per cent more efficient and used much cheaper gas. ${ }^{35}$ The net result of the REC's power plants was:

- By 1998, about 20 per cent of electricity demand was met by gas-fired plants that were effectively out of the market; and

- This power proved expensive and was allocated to the household market;

\footnotetext{
${ }^{34}$ For an account of nuclear power in Britain from 1990-96, see G MacKerron (1996) 'Nuclear power under review' in J Surrey, 'The British electricity experiment' Earthscan, London, pp 138-63.

${ }^{35}$ S Thomas (1997) ‘Good deals gone bad?’ Financial Times Energy Economist, May 1997, no 187.
} 


\subsubsection{Assessment of the Power Pool}

If the contribution of the coal plants, nuclear plants, imports and the RECs' plants is added up, it is clear that more than 95 per cent of RECs' needs were supplied from sources that were not required to compete at all in the Pool. The low real liquidity of the Pool and the scope for price manipulation through the capacity payments system meant that Pool prices were far too variable and unpredictable for retailers to rely on for more than a small element of any balance of their supplies. Nevertheless, by 1997, the coal contracts were nearing an end, the oldest nuclear plants were on borrowed time, imports were no longer subsidised and the residential market was due to open in 1998 appearing to make it more difficult for retailers to pass expensive purchases on to household consumers. As a result, there appeared likely to be significant space in the wholesale market for new generators, especially as the price of power from new plants (then probably less than $2 \mathrm{p} / \mathrm{kWh}$ ) was well below Pool prices (then about $2.5 \mathrm{p} / \mathrm{kWh}$ ) and way below the price most power was actually bought and sold at (more than $3 \mathrm{p} / \mathrm{kWh}$ ). Encouraged by the apparent success of Enron 'wheeling and dealing' in wholesale markets, a number of new entrants began to build new gas-fired plants that would survive purely on Pool receipts: so-called 'merchant plants'. The New Labour government elected in 1997 put an end to this burst of new gas-fired plants soon after it was elected, but by then, about $10 \mathrm{GW}$ of plants, almost all being built by companies other than the duopoly and the RECs was judged to be already too far advanced to be stopped.

Two other early decisions by the new government and the Regulator removed the rationale for these merchant plants. Bids by the duopoly for supply businesses were allowed and it was immediately clear that the 14 British retail businesses would quickly be bought by generators who were likely to buy their power needs from their own plants rather than from merchant plants. The regulator and government also announced that the Pool would be abandoned. ${ }^{36}$ While the exact specification of the new market, the New Electricity Trading Arrangements (NETA), was not given, it was clear the market would parallel that being introduced for gas. The market would not be compulsory and it was expected that more than 90 per cent of power would be bought and sold under long-term confidential contracts. The fact that the Pool was compulsory and that deals in the spot market were bilateral meant that generators had to find a specific buyer for their power either in the spot market or, more likely, under long-term contracts. They could not just dump it into a Pool. Merchant plants had poor prospects in such a system. As a result, some of the merchant plants got long-term contracts, some were abandoned and some were sold to new owners.

Overall, it is clear that the detailed design of the Power Pool was poor, but the concept of a universal Pool was never tested. There remains discussion in Britain about whether a pool type market, without the flaws in the Power Pool, would be a better market design than the design that replaced it. ${ }^{37}$ Thomas raised doubts that a compulsory Pool in a de-integrated market would provide security of supply because there was no mechanism to ensure supply and demand balanced. ${ }^{38}$ The fact that the wholesale price was well above the cost of entry from 1990-98 meant that there were strong incentives to enter and maintain capacity in service. The adequacy of the Pool in terms of supply security would only have been tested if the Pool price had fallen to a more appropriate level in that period.

\subsection{NETA}

To some extent, the details of NETA are irrelevant. The key points were the decision to allow vertical integration and the expectation that the spot market element of NETA would account for less than 10 per cent of wholesale power sales with the rest taking place through confidential self-dealing or contracts. This meant that the price-setting forum was highly unlikely to be the open, transparent and highly

\footnotetext{
${ }^{36}$ Office of Electricity Regulation (1998) 'Review of Electricity Trading Arrangements: framework document.' Office of Electricity Regulation, Birmingham.

${ }^{37}$ R Green (2003) 'Failing electricity markets: should we shoot the pools?' Utilities Policy, 11, pp 155-67.

${ }^{38}$ S D Thomas (1994) 'Will the UK Power Pool keep the lights on?' Energy Policy, vol 22, no 8, pp 643-47.
} 
competitive spot market it was expected to be in 1990 when it was forecast that 'grid company will be calling up the generators which offer the cheapest energy'.

In August 2000, the Regulator decided that NETA would be extended to cover Scotland as well as England \& Wales and in February 2004, it was expected that the British Electricity Trading and Transmission Arrangements (BETTA) would be implemented in April 2005, a year later than was forecast in 2000.

\subsubsection{The principles of NETA}

NETA proved highly costly and took far longer to develop than was expected. It finally went live in 2001, more than three years after the decision to abandon the Pool was taken. The cost of development and of running the system for the first five years totalled about $£ 770 \mathrm{~m}$ according to the UK National Audit Office (NAO). ${ }^{39}$ The NAO stated that NETA was more costly than the Pool arrangements but did not estimate the extent of these extra costs.

While the detail of NETA is complex, the essential principles are simple. There are three parts to the market. Up to 24 hours ahead of the given half hour, power is bought and sold through long-term confidential contracts (not disclosed to the Regulator). This is similar to the situation under the Pool although as there is no marker price in NETA and generators are not required to place a bid for plant they wish to operate, contracts for differences are not possible or necessary. From 24 hours to 4 hours before consumption, power was bought and sold on open, privately operated power exchanges. Subsequently, the closure of the spot markets has been moved to only one hour before the time of consumption. The deals in the spot market are bilateral and are settled at the price registered on the power exchange. At market closure, generators must inform the TSO of plants they contracted to operate and the output from each. Retailers must also declare the amount they are contracted to buy, which should be the amount they expect their consumers to consume. Inevitably there is an imbalance between the sum of the intentions of the individual generators and retailers, and the (more accurate) forecast of demand made by the TSO. The TSO must then buy additional power or pay generators in the Balancing Market (BM) not to generate so the system actually balances. They must also deal with any issues of congestion.

\subsubsection{NETA in practice}

The decision to allow integration of generation and retail and policy of generator/retailers to buy power plants or sign long-term power purchase contracts sufficient to cover much of their needs inevitably meant that the NETA spot markets would have very low liquidity and spot prices would be no more reliable than under the Power Pool. A price index is published but it is unlikely to reflect the cost at which much power is bought and sold. Two power exchanges were set up, UKPX and APX UK, but in December 2003, UKPX was taken over by APX UK (subject to approval by electricity and financial regulatory authorities). In the second half of January 2004, the typical daily volume on the power exchange was about $8 \mathrm{MWh}$, less than 1 per cent of demand. ${ }^{40}$

There have been a number of practical problems mainly associated with the BM. In a thermal power system the costs of short-term increases in production are unpredictable, but likely to be high. Starting up a thermal power station is a lengthy process taking several hours and with significant costs. Retailers that underestimate their consumers' demands in any half hour period will have the balance effectively bought for them by the TSO at the system buy price (SBP). Generators that do not fulfil their contract output will also have the balance bought at the SBP. The cost of reducing output is much less than increasing output and the costs to a retailer of over-forecasting demand or under-forecasting output (the system sell price or

\footnotetext{
${ }^{39}$ National Audit Office 'The New Electricity Trading Arrangements in England and Wales' Report by the Comptroller and Auditor General HC 624 Session 2002-2003: 9 May 2003

${ }^{40}$ Volumes and prices for the UKPX are published fortnightly in a newsletter, Power in Europe (McGraw Hill).
} 
SSP) should be much lower. Generators that cannot easily forecast their available output, for example wind generators or co-generators, are likely to have difficulty. ${ }^{41}$

In practice, things are made more complicated by the fact that the consumption of small consumers is not accurately measured. Meters that measure and transmit half hourly consumption data are far too expensive to install and operate for small consumers and consumption is estimated by allocating consumption over the meter reading period (once a quarter) using a procedure known as profiling. This means that NETA accounts take 15 months to settle while meter readings are taken and the consumption of each retailer's consumers is estimated.

SBP has been highly volatile. ${ }^{42}$ For example, in August 2003, a time of year when demand is low and prices should be correspondingly low, the highest half hourly SBP was more than $£ 400 / \mathrm{MWh}$, about 20 times the average wholesale price of less than $£ 20 / \mathrm{MWH}$. On another day in that month, the average for the whole day was more than $£ 100 / \mathrm{MWh}$. Any generator over-forecasting its output on that day, for example if a plant broke down would have suffered very heavy penalties. While SSP is consistently lower than SBP, the differential is not as large as might be expected and SSP peaked at nearly £300/MWh with an average on one day of over $£ 80 /$ MWh. Volume in the 'System Buy' part of the BM in August 2003 was 427GWh (about 1.7 per cent of demand) and in the 'System Sell' part of the BM was 694GWh (about 2.8 per cent of demand). It seems that generators and retailers are consistently forecasting supply and demand so the probability of paying SSP prices is much higher than having to pay SBP prices and this is creating upward pressure on SSPs.

Table 4 The Balancing Market: August 2003 (price in $£ / M W h$ )

\begin{tabular}{|l|l|l|}
\hline & Low & High \\
\hline Daily average SBP & 12.75 & 115.91 \\
\hline Daily maximum SBP & 17.28 & 408.56 \\
\hline Daily minimum SBP & 2.05 & 13.28 \\
\hline Daily average SSP & 8.99 & 83.36 \\
\hline Daily maximum SSP & 13.84 & 283.79 \\
\hline Daily minimum SSP & 2.05 & 11.23 \\
\hline
\end{tabular}

Source: Power UK

The result of this market has been that renewable and cogenerators have struggled to remain in business ${ }^{43}$, although the Regulator claims that small generators with unpredictable amounts of power to sell are not disadvantaged by NETA. ${ }^{44}$ There has been a marked increase in spinning reserve and part-loading of units as generators ensure they can quickly increase output to take advantage of high SBPs. Clearly, NETA favours large integrated companies that can forecast demand more accurately and that are more likely to have spare plant available to cover plant breakdowns. The NAO in its report on NETA came to no conclusions on this issue.

\subsubsection{Impact of NETA}

In the years before the introduction of NETA and in the following two years, the apparent wholesale electricity price has fallen heavily. The NAO estimated that wholesale prices fell by over 20 per cent between the introduction of NETA in March 2001 and October 2002 and by 40 per cent since NETA was proposed in $1998 .^{45}$

\footnotetext{
${ }^{41}$ The sum of the intentions of generators and retailers will be made up of some over-forecasts and some under-forecasts so the total income from SBP and SSP payments will far exceed the actual sum paid to balance the system. The excess money, usually known as the 'Beer Fund' is recycled to NETA members.

${ }^{42}$ Volumes and prices for the BM are published monthly in a newsletter, Power UK (McGraw Hill).

${ }^{43}$ See ILEX Energy Consulting (2002) 'Addressing the issues imposed by electricity trading arrangements on the development and operation of small generation' ILEX, Oxford.

${ }^{44}$ Ofgem (2003) 'Smaller generator issues under BETTA - An Ofgem/DTI consultation document', Ofgem, London

${ }^{45}$ National Audit Office (2003) op cit.
} 
The Regulator and government have been quick to claim the credit for this, suggesting it was the result of the expectation of the impact of NETA in the years before it was introduced and it was the efficiency of the market that forced prices down after the introduction of NETA. These claims seem hard to justify. It is difficult to understand what mechanism would lead to lower prices before the new market was introduced. And given that most power is bought and sold under long-term confidential contracts, the government and the Regulator cannot know accurately what the wholesale price actually was.

Alternative, more plausible factors behind the reduction in wholesale price are the end of the high-priced coal contracts in 1998, the surplus of capacity that resulted from the burst of new power plant orders in 1997 and the over-contracting for fuel on take-or-pay contracts.

If we look at the impact of this price reduction, another possible factor, which also explains the bankruptcies amongst the non-integrated generators, emerges. Reductions in the spot price and to shortterm contracts linked to spot prices would have a severe effect on non-integrated generators who would see their income fall steeply. This is clearly shown by British Energy, a company with only weak longterm contractual cover. In its 2002/03 annual report, it stated the average spot price was $£ 15.48 / \mathrm{MWh}$ while its average sale price was somewhat higher at £18.30/MWh. British Energy. In 1998/99, its average selling price had been $£ 26.40 / \mathrm{MWh}$, so income for British Energy fell by 30 per cent and it is therefore no surprise the company is in financial difficulties.

For the integrated companies, which primarily generate for their own consumers, their income will only fall if they pass the apparent price reductions on to final consumers. The NAO found;

\begin{abstract}
'Prices paid by industrial and commercial customers have fallen sharply since NETA was implemented. Consumers who switch supplier can see substantial reductions. However, prices that domestic consumers pay for electricity have not fallen much since NETA was implemented, although they have fallen broadly in line with the trend in suppliers' overall costs since 1998. The prices that industrial and commercial consumers pay for electricity have fallen by 18 per cent since the start of NETA, and by 30 per cent since April 1998. Prices for domestic consumers have fallen little since the start of NETA but by 8-17 per cent since April 1998, reflecting the much higher costs of supplying domestic consumers which have been rising due to new environmental costs and the substantial costs of processing changes of supplier.'
\end{abstract}

The issues surrounding retail competition are discussed in more detail in the next section.

\title{
4.2.4 Security of supply
}

Both the government and the Regulator are against measures, such as capacity payments, that try to ensure that there is sufficient capacity to meet demand. In its White Paper on Energy Policy, the government affirmed its determination not to intervene in the market 'except in extreme circumstances, while the Regulator stated: 'we do not have any new evidence or arguments that suggest that capacity payments are necessary to promote security of supply or would be cost-effective at increasing security of supply. ${ }^{, 4}$. In respect of security of supply, NETA differs little in practice from the Pool in relying solely on market forces to stimulate investment. The Pool did have a capacity payment mechanism, but this was so hopelessly misconceived as to be irrelevant for these purposes.

The NAO, noting that 'NETA relies on market signals to ensure security of electricity supplies', said:

'In recent years, including since NETA was introduced in March 2001 until autumn 2002, there has been an annual margin of generating capacity over expected demand of at least 20 per cent and as yet no risk to supply is in prospect. If however generating plant is withdrawn from the market faster than it is replaced the margin of supply over demand will reduce.'

The surplus of capacity reflected the surge of orders of 1997 placed on the mistaken belief that wholesale prices would remain high and that there would be a market for output from independent power producers. This surplus also contributed to the steep fall in the apparent wholesale electricity price. By September 2003, four months after the study was published, low wholesale market prices had led to just such a

\footnotetext{
${ }^{46}$ UK government (2002) 'Energy White Paper' paragraph 6.7.

${ }^{47}$ Ofgem 'Proposed Corporate Strategy 2004-2007', Ofgem, London
} 
withdrawal of capacity. A large proportion of non-integrated generators were bankrupt and a significant amount of modern generating plant was mothballed. The National Grid Company was forced to warn of a possible shortage of generation for winter 2003/04 and to encourage generators to bring plant back into service. This quickly happened and the potential problems were quickly averted.

However, this gives little comfort. The existence of a large volume of mothballed plant cannot be assumed for the future. This was a hangover from the 1997 'dash-for-gas'. For the future, growth in demand and replacement of retired plant will have to rely on market signals to stimulate new investment. This raises two issues: will the price signals be timely and will financiers be willing to fund investment?

On the first point, recent history is not encouraging. In 2002, wholesale prices were at rock bottom levels, yet only a year later, there was a risk of capacity shortage (quickly met by mothballed plants). Given that large power plants need more than 3 years from start of planning to first power, there seems a serious risk that the price singles seem likely to emerge too late, at best leading to very high short-term prices (witness events in California in 2000) and at worst leading to power blackouts. Experience on the second question is equally poor. Nearly all the investment in generating plant since 1990 has provided poor rates of return:

- The 'dash for gas' plants built by National Power and Powergen lost them large amounts of money ${ }^{48}$ and contributed to the weakness that led to their takeover;

- The 'dash for gas plants' built by the RECs proved very high cost. The REC retail businesses still seem to be passing on these high costs to small consumers and contributing to the inflated price small consumers must pay for power;

- The $£ 3$ bn of consumers' money invested in the Sizewell B nuclear power plant was lost only a year after the plant was completed when it was essentially given away in the privatisation of British Energy

- Despite being essentially given eight modern nuclear power plants, British Energy was bankrupt only six years after its creation and shareholders have lost their money. Future taxpayers will also be saddled with high costs from the disposal of waste and spent fuel and from the decommissioning of the plants;

- The companies that built plant in the second 'dash-for-gas' of 1997 appear also to have fared badly. Many of the plants were sold, on or before their completion; and

- The American companies that entered the market in 1999-2001, buying about 12GW of existing plants were all in serious financial problems by the end of 2001. The plants were either repossessed by the banks that lent money for their purchase or are for sale at distress prices.

The message to investors is clear. While there must be doubts about whether the British wholesale electricity market is a competitive and efficient one, it is a very risky one. Financiers will need strong evidence that new investment will not be as economically disastrous as most investment in Britain has been since 1990 if they are to provide further capital for power plants in Britain. The one set of companies in which investment risk may be tolerable is the large integrated companies. These will have reasonable assurance of a market for the power and if power produced is expensive, it can probably be passed on to residential consumers who are probably not cost-sensitive enough to react. ${ }^{49}$

Whether integration of generation and retail will deliver supply security because individual integrated companies will ensure they have enough power to meet their consumers' demands either via their own plants or via long-term contracts is not clear, but if it does it will be at a heavy cost to consumers. An

\footnotetext{
${ }^{48}$ In 1998, Powergen renegotiated gas contracts at a cost to the company of $£ 535 \mathrm{~m}$. In November 1999 , National Power also announced provisions for losses on its gas contracts of $£ 759 \mathrm{~m}$.

${ }^{49}$ Having an integrated business does not offer total protection. TXU owned the retail businesses of two RECs and had a significant amount of generating plant. However, it seems to have over-contracted for power and paid too high a price for it. As a result, it went bankrupt in 2002 and was bought by Powergen/E.ON
} 
oligopoly of weakly regulated, integrated retailer/generators passing on high cost power to small consumers would be a poor outcome.

A comparison with NordPool, the market that covers the four Nordic countries is instructive. Here there is a mixture of integrated and non-integrated companies. However, since liberalisation (in 1991 for Norway, 1995 for Sweden and Finland, and 1997 for Denmark) there has been minimal investment in new generation. The pre-existing capacity surplus and the low demand growth in the region have meant that up to 2003, this had posed no problems. But in 2003, Nordel began to express concerns about capacity adequacy. ${ }^{50}$ If capacity shortages do occur, the high reputation of NordPool will soon be lost.

\subsubsection{Assessment of NETA}

There are a number of concerns about NETA. There is a vicious circle with the spot market. There is a lack of liquidity in the spot market because prices are not consistent and prices are not consistent because of a lack of liquidity. The contract market is opaque and dominated by long-term confidential contracts. This vicious circle of lack of liquidity and lack of trust is compounded by the fact that the market is dominated by integrated companies that have no interest in promoting a liquid spot market and contract market. If there is not a liquid spot and contract market, the barriers to entry for new generators and new retailers will be high. New generators will have no market for their power because integrated companies will prefer to use their own plants while new retailers will not be able to buy wholesale supplies reliably because integrated companies will have no interest in allowing new competitors into the market by selling power to them cheaply.

There is no evidence that the integrated companies deliberately pushed down the spot price and the shortterm contract price by dumping power on to the market to force the independent generators out of the market. But clearly a lack of independent generators is to their advantage.

A comparison with NordPool is again instructive. Like NETA, NordPool has a voluntary spot market, but unlike NETA liquidity is of the order 25 per cent. Perhaps the key differences are that the NordPool spot market was based on a long-established and well-trusted spot market set up in Norway in 1971, long before liberalisation was introduced. A significant proportion of the retail market is not covered by fully integrated companies. At the margin, the capacity is generally hydro-electric plants with very fast response times, so there is little justification for high prices in the balancing market. The majority of the companies are publicly owned or controlled this may mean that they are less likely to exploit opportunities in the market for short-term profit. The Nordic countries got round the issue of dominant players by integrating their markets. Nationally owned companies in Finland (Fortum), Norway (Statkraft) and Sweden (Vattenfall) dominated their national generation markets with 40-60 per cent market shares, but in a Nordic market, their individual shares were below 20 per cent. However, since the completion of the NordPool market in 1997, there has been a trend of takeovers and mergers, integration of generation and retail supply and pressure to privatise the national companies. If this trend continues unchecked, the Nordic market could yet evolve into a similar structure to that found in Britain: a market dominated by a highly concentrated, integrated, privatised set of companies.

Overall, it seems no more possible to form a judgement on NETA than it was on the Power Pool. The Pool was never properly tested because of the existence of long-term contracts and power purchase obligations, which meant there was no scope for the Pool to provide a marker price. NETA is similarly restricted in its liquidity by the decision to allow integration of generation and retail, which has again left little scope for buying on the spot market. A Pool system has some theoretical advantages over a

\footnotetext{
${ }^{50}$ In its capacity report of November 2003, it wrote concerning the ability of the system to survive 1 in 10 year climatic conditions 'By taking into account estimated import from outside of the Nordel area and power exchange between the Nordic countries, the whole Nordel area seems to be in balance. However, without expected import there is a quite clear underbalance in the Nordel area'. Nordel (2003) 'Power balance 2003/2004', Nordel.
} 
voluntary spot market. It should reduce the barriers to entry for new generators and retailers and the lack of a balancing market makes life much easier for small (usually environmentally attractive) generation sources that cannot easily predict their availability. However, neither system seems able to guarantee security of supply. Various forms of capacity payment have been introduced in other electricity wholesale markets, but there must be doubts whether a capacity payment system can be introduced that does guarantee sufficient capacity is available without seriously compromising the requirements of a free market, for example, free entry and exit.

\section{Is retail electricity competition resulting in an efficient allocation of costs?}

When the British reforms were introduced in 1990, it was planned that retail competition be introduced in three stages, for large consumers in 1990 (those with a maximum demand above 1MW), for medium consumers in 1994 (those with a maximum demand above of 100kW), and for all consumers in 1998. Few envisaged in 1990 how this would work for small consumers in practice, while analysis of the costs suggested that there would be little for retailers to compete over. Most of the price of electricity for small consumers was either standard monopoly charges (distribution and transmission, about 30 per cent) or generation (65 per cent). If the Pool worked as expected, with all power being bought at Pool or Poolrelated prices, it was difficult to see how one retailer could buy more cheaply than another. Retailers' costs then represented only about 5 per cent of small consumers' bills so there seemed little to compete over. For large and medium industrial consumers, a price reduction of only one or two percent would be worthwhile, but for small consumers savings of a few pounds per year are unlikely to cause much interest.

There were significant practical problems in introducing competition for medium and large consumers ${ }^{51}$ but these were overcome and such consumers soon got used to changing supplier or renegotiating their terms annually and have received significant price reductions. The costs of introducing competition for such consumers, for example in metering, are small compared to the overall bill. It seems therefore likely that large and medium consumers will always have the incentive and the capabilities to take advantage of market-opening to reduce their costs. The important issues are the impact of competition on how costs are distributed between different classes of consumer and the cost and practicalities of introducing competition for small consumers.

\subsection{The impact of competition on how costs are distributed}

It became clear in 1998 that the price reductions received by large consumers were largely received at the expense of small consumers. The Regulator published data that showed that retailers were systematically allocating their expensive wholesale purchases to the captive market and their cheap purchases to the competitive market. The expensive purchases were the coal generation and the dash-for-gas plants built by the RECs, while the cheap purchases were the nuclear plants and imports.

Ironically, the nuclear power was cheap only because of the subsidy consumers had given to nuclear from 1990-96 (£6bn) and because the money spent by consumers building the plants was effectively written off when the plants were privatised in 1996. The Regulator was in a difficult position with the expensive power. While he was required not to allow discrimination between consumers, the coal contracts, brokered by the government were only signed on the basis that retailers could allocate this power to the small consumers, so it would have been difficult to prevent the companies discriminating in this way. On the REC plants, the Regulator had examined these in 1992 under his obligation to ensure that RECs purchased power 'economically' and found that they met this criterion, so he had already compromised his position on these plants.

The impact of this segmentation of contracts was that small consumers were paying 30 per cent more for the generation element of their bill than large consumers (see Table 5). If generation cost had been

\footnotetext{
${ }^{51}$ D MacLaine (1999) 'The UK electricity supply market’ Financial Times Energy, London
} 
equalised over all consumers, prices for small consumers would have come down by about 7.5 per cent. The Regulator was forced by the Energy Select Committee of Parliament to provide a cost benefit analysis of the introduction of retail competition for small consumers. ${ }^{52}$ A major element of the benefits was that competition would ensure retailers would not be able to pass on expensive power costs to consumers. Given that the coal contracts, a large part of the 'expensive' power, were due to come to an end in 1998 at the same time as retail competition was expected to be introduced, it was somewhat disingenuous to claim this as a credit for retail competition. Commentators also questioned other aspects of the analysis. ${ }^{53}$ Nevertheless, the implication of the analysis was clear: all consumers would pay about the same for generation as each other and companies that had expensive power purchases would have to write off the additional cost of such contracts against profits.

\section{Table 5 REC Purchase Costs - 1996/97}

$\begin{array}{cll} & \begin{array}{l}\text { Average price } \\ (\mathbf{p} / \mathbf{k W h})\end{array} & \begin{array}{l}\text { Quantity } \\ \text { (TWh) }\end{array} \\ \text { Franchise consumers } & & 71.7 \\ \text { Coal contracts } & 3.92 & 28.9 \\ \text { IPP contracts } & 3.84 & 34.3 \\ \text { Other contracts } & 3.71 & 134.9 \\ \text { Average franchise purchase costs } & 3.85 & 80.4 \\ \text { Non-franchise purchase costs } & 3.00 & 215.2 \\ \text { Average total purchase costs } & 3.54 & \end{array}$

Source: Office of Electricity Regulation (1997) 'The competitive electricity market from 1998: price restraints: proposals' OFFER, Birmingham.

The NAO report demonstrates clearly that this has not happened. Retailers are still allocating their expensive power purchases to the residential market. Worse, while supply was still a monopoly, the retailers could only pass on the actual cost paid for generation (albeit their most expensive contracts), now prices are unregulated and retailers can add on any profit margin they like. Transmission and distribution costs are still set but retailers are free to increase their retail margins as much as the market can bear. Power $\mathrm{UK}^{54}$ reported that while wholesale prices went down by 35 per cent from January 1999 to January 2002. But the price paid by large consumers for their generation and retail elements of their bill had gone down by only 22 per cent, while the amount paid by small consumers had actually gone up by 5 per cent.

Within the category of residential consumers, there is also evidence that retailers are targeting the richest consumers who are more profitable and who are more likely to buy other products (telecoms, gas, financial services etc) from the electricity retailer. ${ }^{55}$ Those consumers that pay by 'Direct Debit' (a predetermined amount taken directly from the consumer's bank account) get the lowest prices, while those using pre-payment meters (about 15 per cent of consumers) get the highest prices.

\subsection{The practicalities of introducing competition for small consumers}

The main practical difficulty in introducing retail competition is metering. If wholesale prices are settled every 30 minutes, and retailers no longer have a monopoly in a given franchise area, it is necessary to know how much power each consumer has used in each 30 minute period if retailers are to be billed accurately by the wholesale market for the power their consumers use. The ideal solution is an electronic

\footnotetext{
${ }^{52}$ House of Commons Trade and Industry Committee (1998) 'Developments in the Liberalisation of the Domestic Electricity Market' Select Committee on Trade and Industry Tenth Report, HC871, House of Commons, London.

${ }^{53}$ For example, R Green \& T McDaniel (1998) 'Competition in electricity supply: will “1998” be worth it', PWP-057, University of California Energy Institute and S Thomas (1998) ‘An unanswered question’ FT Energy Economist, no 196, pp 28

${ }^{54}$ Power UK 'Prices fall for some but stay the same for others' Power UK 97, March 2002, p 27.

${ }^{55}$ K Jewell (2003) 'Manipulated, Misled, Ignored, Abused: Residential Consumer Experience with Electric Deregulation in the United Kingdom’, Consumer Union, Texas
} 
meter that has a permanent connection to a data collection point so the consumer's meter can be read every 30 minutes. For medium and large consumers, the cost of buying installing and operating such meters is acceptable (the main cost is not the meter, it is the landline and the processing of the data), but for small consumers, the cost is of the same order as an average electricity bill and is clearly prohibitive. In the long-term, broad band connections and other innovations may make such meters viable but this seems a long way off.

The interim solution chose was to use 'profiling'. Essentially, under profiling, the daily pattern of consumption of all residential consumers is assumed to be the same. There are a number of profiles: according to season, according to day of the week, according to whether the consumer has a night rate meter, etc. When a meter reading is taken (not more often than once every three months), the profiles are used to allocate the three months of consumption to each 30 minute period of the time covered. This is an unsatisfactory process not only because of its obvious inaccuracy. It does not allow consumers to respond to price signals: for example, if power is expensive on the wholesale market at a given time, it might be desirable to give a signal to consumers to reduce consumption and the savings made shared between consumer and retailer. This is only possible if the meter reading is available to show the consumer actually did reduce consumption in the specified period.

Profiling also causes huge problems of reconciling the accounts of supply and demand. Retailers can only be charged for their purchases from the Balancing Market when the final estimate of the consumption of the retailer's consumers is made. Given that meters might not be read for up to a year, this means that NETA is not finally settled until 15 months after the event. A retailer that has underestimated demand at a time when BM prices were high might not know the extent of their penalty until long after the event.

The cost of these measures and the cost of the software to allow consumers to switch supplier was immense. The Regulator's cost benefit analysis showed costs of about $£ 726 \mathrm{~m}$ that would be passed on to consumers as the cost of developing the software and running it for five years. ${ }^{56}$

The NAO identified a number of additional costs to retail competition other than the cost of building and operating the software to allow switching, which would not apply in a monopoly market. These included: 'customer acquisition and brand building costs, increased bad debt since customers gained the ability to switch, higher depreciation charges on upgraded IT systems to deal with competition and the higher costs of customer care.' Retailers' costs are now estimated to represent 30 per cent of consumers' bills. Comparisons with the position in 1990 when retailers' costs represented only 5 per cent of a typical bill are difficult because some costs previously allocated to distribution were moved to supply in 1998, but it is clear there has been a huge increase in retailer costs.

Costs of customer acquisition have been particularly high. Winning customers individually, for example by door-step selling or advertising in the media, has proved costly, controversial and unrewarding. The reputation of companies has suffered from continual examples of fraudulent selling practices ${ }^{57}$ and many of the consumers won directly, appear to be those most likely to switch again often back to the local supplier. ${ }^{58}$ As a result of this, the main method of acquiring consumers has been through corporate takeovers of retail businesses, where prices in excess of the equivalent of $£ 180-300$ per consumer have been paid. ${ }^{59}$ Given that the average annual bill for a residential electricity consumer is not much more than $£ 200$, if such high costs are to be paid back, the companies must rely on a very high level of loyalty, a high level of operating profit and good prospects of selling other services such as gas.

\footnotetext{
${ }^{56}$ House of Commons Trade and Industry Committee (1998) op cit

${ }^{57}$ For example, in November 2002, London Electricity (owned by EDF) was fined $£ 2 \mathrm{~m}$ for mis-selling. And in 2003 , two further companies were fined for inappropriate marketing activities.

${ }^{58}$ By 2002, about a third of those that had switched supplier had switched more than once and nearly half the multiple switchers went back to their local supplier.

${ }^{59}$ For example, the EDF purchase of the SWEB retail business in 1999 was equivalent to about $£ 180$ per consumer.
} 
The NAO reported that the price paid by residential consumers for electricity fell by 8-17 per cent from 1998 to 2003 during which period, it estimated wholesale prices had fallen by 40 per cent. In 1998, generation represented about 50 per cent of small consumers' bills and as argued earlier, small consumers were then paying 15 per cent too much for their generation. If the wholesale price reductions had been passed on to small consumers, prices would have come down by 20 per cent. However, in that period, reductions in distribution and transmission prices should have reduced prices by about 9 per cent. It seems that little or none of the wholesale price reduction was passed on to small consumers and in total, small consumers seem to be paying nearly 30 per cent too much for their power. However, in 2003, wholesale prices began to rise steeply, increasing by about 15 per cent. Retailers have been quick to raise their prices in first quarter 2004, typically by about 6 per cent, overtly to cover these wholesale price increases.

\subsection{Assessment of retail competition}

At the time of privatisation, it seemed that retail competition was of more symbolic importance, demonstrating to consumers that the old monopolies really had been removed, than as a price reducing mechanism. However, as the wholesale market has been increasingly compromised by long-term contracts and integration of retail and generation, the role of retail competition becomes more important.

If electricity companies are to be subjected to competitive forces, it will be through consumers ruthlessly switching supplier regularly to the cheapest supplier. Large consumers already do this and have improved their terms of supply as a result. If small consumers did this, the switching costs, ironically borne by all consumers including those that did not switch, would be immense. The British Energy Minister, Brian Wilson said in May 2003 'The benefits of price falls must not be restricted to those who switch, not least because if everyone starts to switch, the costs of administering this will outstrip the savings. ${ }^{60}$ However, small consumers are unlikely to do this because they do not have the resources, the confidence or the incentive to do so. This inertia will be reflected in the high prices they will have to pay.

\section{Why have prices gone down ${ }^{61}$}

A detailed analysis of why prices have fallen for small consumers since 1990 is beyond the scope of this paper. Nevertheless, it is not difficult to isolate the main factors behind the price reductions. The first point to note is that in the run up to privatisation in 1988 and 1989, the government increased electricity prices by 7 per cent over and above that required by the electricity industry, in order to improve the attractiveness of the industry to investors. ${ }^{62}$ Any reductions since 1990 must be seen in the light of these increases. However, the two dominant elements of the price reductions since 1990, now standing in real terms at about 30 per cent, are clear and neither was the direct result of the operation of markets.

The removal of the nuclear subsidy in 1996 reduced prices overnight by 10 per cent. This was possible in part by improved efficiency in the nuclear industry (ironically while it was in public ownership and largely insulated from the market). But the bankruptcy of British Energy and the placing of heavy liabilities on future taxpayers now make the removal of the subsidy seem questionable. The NAO was highly critical of the government's conduct in the privatisation of British Energy, suggesting that the government failed to assess adequately the risk to taxpayers of the privatisation, in the form of long-term liabilities that inevitably revert back to taxpayers in the event of corporate failure. ${ }^{63}$

\footnotetext{
${ }^{60}$ Power UK June 2003 Issue 112 p. 29

${ }^{61}$ A counterfactual analysis of electricity prices in Britain since 1990 by Branston, published in 2000 found that 'observed prices are indeed significantly higher than they would have been had privatisation not occurred'. Branston, J. Robert. (2000). "A Counterfactual Price Analysis of Electricity Privatisation in England and Wales", L'institute Discussion Paper 7 , Universities of Birmingham, Ferrara and Wisconsin-Milwaukee.

${ }^{62} \mathrm{G}$ Yarrow (1992) 'British electricity prices since privatisation' Studies in regulation, no 1, Oxford Regulatory Policy Institute, Oxford.

${ }^{63}$ National Audit Office (2004) 'Risk Management: The Nuclear Liabilities of British Energy plc', National Audit Office HC 264 Session 2003-2004: 6 February 2004
} 
An even larger part of the price reductions came about because of the reduction in monopoly prices. For example, from 1990-2003, the real distribution price charged in the Southern region of Britain (not untypical) fell by 50 per cent and the national transmission price fell by 40 per cent. Given that in 1990, distribution and transmission accounted for about 25 per cent and 5 per cent respectively of consumers' bills, these price reductions alone would have reduced the overall price by about 15 per cent.

This leaves the reductions in monopoly prices as the apparent success story of privatisation. ${ }^{64}$ However, even here, all is not as it seems. Prior to privatisation, prices for these services were effectively set by a rate of return methodology. Under this, the allowed income of the company was calculated as the sum of a fair rate of return on the value of assets owned plus the running costs. In short:

\section{Allowed income $=($ Asset value - depreciation + new investments $) *$ Rate of return on assets + Running costs}

After privatisation, charges continued at about the level that existed before privatisation and changes in the price were set by the 'incentive formula', RPI-X (where RPI or Retail Price Index is a measure of consumer price inflation and $\mathrm{X}$ is the target percentage efficiency improvement the company must make if it is to maintain its profitability). Under this formula, regulated companies were allowed to increase their prices by the rate of inflation minus the $\mathrm{X}$ factor. The initial $\mathrm{X}$ factors set by the government for the distribution companies applied until 1995 and were extremely generous allowing the companies to increase their prices in real terms.

This methodology proved inappropriate and it became clear that prices for such services could only be properly set by reference to the amount of investment the company had to make. From 1995 onwards, prices were therefore set by rate-of-return methodology, although the results were still presented as ' $\mathrm{X}$ ' factors. When the change to rate-of-return methodology occurred, the regulator had to set a value on the assets built before privatisation. He had two basic options: he could have used the value of assets as set out in the nationalised companies' accounts, or he could have used the privatisation sale price. The former would give consumers the appropriate price signals on the cost of the facilities they were using. But the privatisation price was only about a third of the asset value, and using the accounting value would have given the new owners unearned profits. He chose, probably correctly, to use the privatisation price as the value of the assets. Since this was only about a third of the accounting value of the assets, this led to immediate, large, one-off price reductions. In 1997, the transmission prices were reduced overnight by 20 per cent, while in 1995/96, distribution prices were reduced by about 25 per cent varying from region to region (see Tables 6 and 7).

If we assume, for example, that the 'return on assets' term represented about 60 per cent of the income of the network businesses before privatisation, writing off two thirds of the assets would reduce prices by about 40 per cent. We can assume that if the industry had not been privatised, it would have continued to improve its operating efficiency at something like the rate it achieved in the 1980s, of about 2 per cent per year, that is, about 25 per cent over the period 1990-2004. If we apply this figure to the operating costs and we assume these represent 40 per cent of income, prices would go down by another 10 per cent. In this light, reductions of 40-50 per cent in monopoly prices do not look so impressive.

Two things are worth noting about these price reductions. First, they may only be temporary. As new assets are bought to replace the pre-privatisation assets, purchased at full costs, prices will go back up again. Second, price reductions were paid for by tax-payers who saw assets they owned sold for only a third of their value.

\footnotetext{
${ }^{64}$ For an account of price regulation, see S Thomas (2001) 'Theory and practice of governance of the British electricity industry’ International Journal of Regulation and Governance, vol 1, no 1, pp 1-24.
} 
Table 6

Electricity Transmission Regulation $(1990=100)$

\begin{tabular}{|c|c|c|c|c|c|c|c|c|c|c|c|c|c|c|c|}
\hline Year & 1991 & 1992 & 1993 & 1994 & 1995 & 1996 & 1997 & 1998 & 1999 & 2000 & 2001 & 2002 & 2003 & 2004 & 2005 \\
\hline $\mathrm{X}$ & 0 & 0 & 3 & 3 & 3 & 3 & 20 & 4 & 4 & 4 & 0 & 1.5 & 1.5 & 1.5 & 1.5 \\
\hline Price & 100 & 100 & 97 & 94.1 & 91.3 & 88.5 & 70.8 & 68.0 & 65.2 & 62.7 & 62.7 & 61.7 & 60.8 & 59.9 & 59.0 \\
\hline Mean X & & 0 & & & & 2 & & & & 4.5 & & & & & 3.5 \\
\hline
\end{tabular}

Source: Author's calculations

Notes:

1. The 2001 review separated the SO function from the transmission assets business. The X factor refers to the much larger transmission assets business.

2. Prices are index numbers net of inflation with $1990=100$

Table 7 Electricity Distribution Regulation - Seeboard (1990=100)

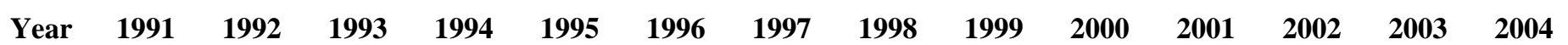

\begin{tabular}{|c|c|c|c|c|c|c|c|c|c|c|c|c|c|}
\hline X & -0.75 & -0.75 & -0.75 & -0.75 & 14 & 13 & 3 & 3 & 3 & 21 & 3 & 3 & 3 \\
\hline Price & 100.7 & 101.5 & 102.3 & 103.0 & 88.6 & 77.1 & 74.8 & 72.5 & 70.4 & 55.6 & 53.9 & 52.3 & 50.8 \\
\hline
\end{tabular}

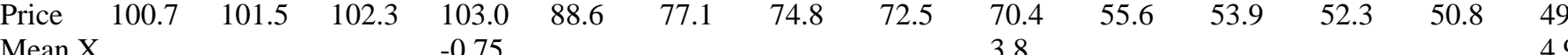

Source: Author's calculations

Notes:

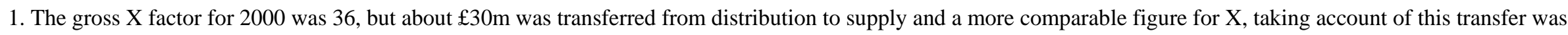
21

2. Prices are index numbers net of inflation with $1990=100$ 
A report by the House of Commons Trade and Industry Select Committee into the 'Resilience of the National Electricity Network' ${ }^{65}$ found that 'there is a danger that there is currently insufficient investment in the network to replace in a planned and orderly way equipment which is reaching the end of its life.' As a result, it expected that capital expenditure by network owners would have to double, raising prices to consumers by $£ 1$ bn per year. The Chair of the Committee said 'the supply system had been "gold-plated" before privatisation but companies had been living off that cushion for too long. 66

This leaves very little of the price reductions to attribute to the operation of markets. Three main factors had led to significant real reductions in costs to generators:

- Fossil fuel prices paid by British generators have fallen substantially in real terms since $1990^{67}$, by about 50 per cent for coal and 30 per cent for gas;

- The electricity industry had been privatised for only about a third of its asset value. This meant that the generators effectively bought their power stations for only a third of their value; and

- More efficient generating technology, the combined cycle gas turbine (CCGT) became available.

The fact that so little of these cost reductions has been passed on to small consumers clearly demonstrates that the wholesale and retail power markets are not efficient.

\section{Conclusions}

An analytical approach to the experience of electricity privatisation in Britain shows that the high reputation of these reforms is not justified. The good results to date are based on three factors:

- Good luck, particularly extremely advantageous fossil fuel markets;

- A significant improvement in the performance of the British nuclear power plants;

- And a transfer of resources from tax-payers to electricity consumers because the industry was privatised for less than a half of its pre-privatisation accounting value.

The central criterion on which the reforms must be judged is the extent to which efficient markets, wholesale and retail, have been created. On this criterion, the reforms have failed. The wholesale market has throughout the period since privatisation been an uncompetitive. Obscure long-term contracts, privileged access to the market and self-dealing within integrated generator/retailers have dominated wholesale purchases leaving the spot markets with minimal liquidity and prices that are not reliable enough for anyone to trust.

The failure to develop a credible, transparent, wholesale market places the onus on the retail market to impose competition on the electricity companies. Large consumers are able to bear this responsibility and have done well from liberalisation. However, these advantages have come at the expense of small consumers, particularly the poorest amongst them and as competition develops, unless government significantly strengthens regulation at the expense of markets, this exploitation will get worse.

The future looks less rosy. Fossil fuel prices are unlikely to fall further, the industry is moving dangerously close to an oligopoly with a veneer of competition and there will be an increasing need for consumers to pay for the replacement of written off pre-privatisation assets at full price.

\footnotetext{
${ }^{65}$ House of Commons Trade and Industry Committee (2004) 'Resilience of the National Electricity Network' Third Report of Session 2003-04 HC 69-1.

${ }^{66}$ Guardian 'Electricity users may face $£ 1$ bn penalty', 11 March 2004.

${ }^{67}$ From 1992 to 2000, the price paid by generators for coal fell by 50 per cent and the price paid for gas fell by nearly 30 per cent. See P Wright and S Thomas (2001) 'Empirical reflections on the liberalisation of the UK electricity supply industry' Economia delle Fonti di Energia e dell'Ambiente', no 2, pp 7-24.
} 